\title{
Quantification of diagenesis impact on the reservoir properties of the Jurassic Arab D and C members (Offshore, U.A.E.)
}

\author{
F. H. NADER ${ }^{1}$, E. DE BOEVER ${ }^{2}$, M. GASPARRINI ${ }^{1}$, M. LIBERATI ${ }^{3}$, C. DUMONT ${ }^{1}$,

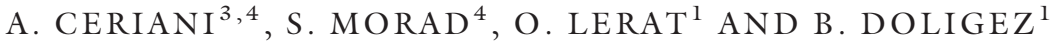 \\ ${ }^{1}$ IFP Energies nouvelles, Rueil-Malmaison, France; ${ }^{2}$ VITO, Antwerp, Belgium; ${ }^{3}$ University of Pavia, Pavia, Italy; \\ ${ }^{4}$ The Petroleum Institute, Abu Dhabi, UAE
}

\begin{abstract}
An increasing need exists to quantify the impact of diagenesis on complex and heterogeneous geological reservoirs and to predict the related field-scale porosity-permeability distribution. Development of approaches to quantify diagenetic events is an important step towards the construction of integrated numerical reservoir models predicting the impact of successive diagenetic events on petrophysical properties at various scales. This article describes two distinct approaches, which allow capturing, quantifying and explaining reservoir heterogeneities of the Jurassic Arab Formation (offshore oilfield in Abu Dhabi, U.A.E.) at the field and plug scale. Based on a classical diagenesis study, whereby the major diagenetic phases were characterized, distribution patterns were highlighted to further explain reservoir heterogeneities through a set of 2D interpolation diagenesis maps across the field. The best reservoir properties are encountered in the central-northern (grainstones with syntaxial calcite overgrowth cement - typical of Arab D) and south-western (dolostones - typical of Arab C) parts of the oilfield. Following another independent approach at the scale of the plug, quantification of rock components and description of the pore space connectivity and geometry are obtained by $2 \mathrm{D}$ and $3 \mathrm{D}$ image analyses, $\mu-\mathrm{CT}$ and pore network modelling. This latter approach resulted in a better understanding of the effect of anhydrite dissolution on the pore structure of the investigated dolostone. The overall, presented workflow provides valuable constraints for assessing reservoir heterogeneities in statistical field-scale models.
\end{abstract}

Key words: dolomite, image analyses, interpolation maps, Micro-CT, reservoir

Corresponding author: F. H. Nader, IFP Energies nouvelles, 1-4 Avenue de Bois-Préau, 92852 Rueil-Malmaison Cedex, France.

Email: fadi-henri.nader@ifpen.fr. Tel: +33147527457. Fax: +33147527126.

Geofluids (2013) 13, 204-220

\section{INTRODUCTION}

Carbonate reservoir rocks are often characterized by substantial heterogeneities resulting in a significant challenge for the optimization of hydrocarbon production and recovery (e.g. Ahr 2008). Methodologies designed to improve reservoir characterization may also be applied for underground storage of gas (e.g. carbon capture and storage CCS), freshwater and geothermal energy applications. Several inter-related factors lead to such complicated heterogeneities, including the depositional settings, diagenetic processes, as well as tectonics and burial/thermal evolution of the basin (Cantrell et al. 2001; Roure et al. 2005; Ehrenberg et al. 2007; Rahimpour-Bonab et al. 2010). This paper deals with the diagenetic processes, which are associated with advective mass flux and/or diffusion in the rock matrix, and controlled by depositional porosity and permeability (Jones \& Xiao 2005; Esrafili-Dizaji \& Rahimpour-Bonab 2009).

To date, classical diagenesis studies make use of a wide range of descriptive methods and analytical techniques converging into conceptual models that explain specific, relatively time-framed, diagenetic processes to deduce their impacts on reservoir rocks (e.g. Nader et al. 2004; Gasparrini et al. 2006; Fontana et al. 2010; Ronchi et al. 2011; Swennen et al. 2012). Currently used techniques combine petrographic (conventional, cathodoluminescence, fluorescence and scanning electron microscopy with energy dispersive spectrometer - SEM/EDS), geochemical (major/ trace elements, stable oxygen and carbon isotopes, strontium isotopes) and fluid inclusion analyses (microthermometry, Raman spectrometry, crush-leach analysis), providing 
independent arguments to support or discard any of the proposed models. More recently, the use of basin modelling is employed to support the burial history evolution (including temperature and pressure boundary data) and the proposed paragenesis (e.g. López-Horgue et al. 2010; Fontana et al. in press). Still, conceptual models are qualitative and do not yield quantitative data to be directly used by reservoir engineers for rock-typing and geological modelling (e.g. Jones \& Xiao 2005; Youssef et al. 2007b; Algive et al. 2009b; Consonni et al. 2010; Lapponi et al. 2011; Barbier et al. 2012; De Boever et al. 2012). Figure 1 illustrates a workflow that aims at predicting the impact of the relevant diagenetic processes on reservoir properties, leading to improved rock-typing and reservoir modelling. This workflow includes three major steps, that is, concept definition, quantification and numerical modelling. Based on well-defined diagenetic processes, this article presents two approaches for the quantitative assessment of their impacts at the field and plug scale (i.e. Fig. 1B).

Results of petrographic studies and image analyses are used in this study to quantify various diagenetic phases in core samples of the D and C Members of Jurassic Arab Formation from 13 wells in one major oilfield offshore Abu Dhabi (U.A.E.). This quantification approach led us to produce field-scale maps, featuring the distribution of the lithology, rock textures and the various diagenetic phases as well as the petrophysical parameters (porosity and permeability). Furthermore, coupling $\mu$-CT 3D image analyses and Pore Network Modelling (PNM) at the scale of a plug allowed to (i) quantify the $3 \mathrm{D}$ rock microstructure and (ii) evaluate, based on a realistic representation of the pore space, the impact of crucial cementation/dissolution processes on reservoir petrophysical properties (e.g. Rhodes et al. 2008; Al-

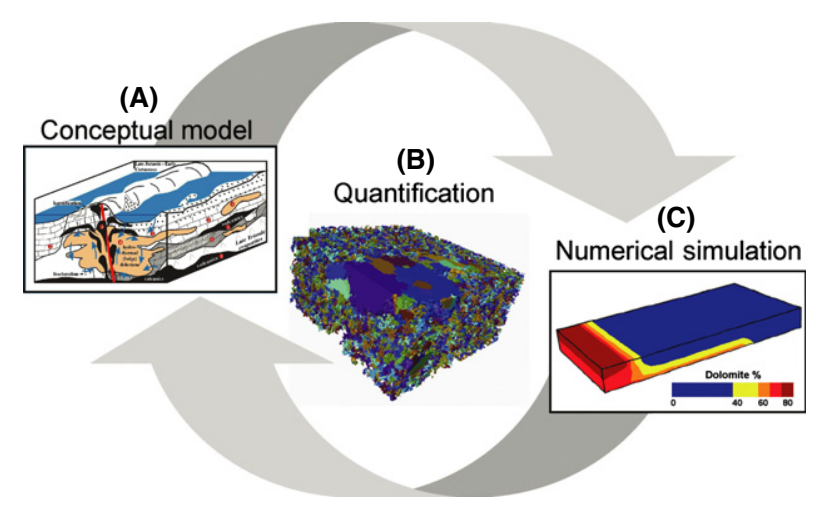

Fig. 1. From conceptual to numerical modelling, a step of 'quantification' remains essential. (A) Conceptual studies of diagenesis - for example hydrothermal or high temperature dolomitization (HTD; Nader et al. 2004, 2007). (B) Quantification methods - e.g. micro-computed tomography $(\mu-C T)$ image analyses (De Boever et al. 2012) and X-Ray diffraction (XRD) combined with Rietveld analysis (Turpin et al. 2012). (C) Numerical simulations of diagenetic processes such as reactive transport modelling of dolomitization (e.g. Consonni et al. 2010). give et al. 2009a,b; Flukiger \& Bernard 2009; De Boever et al. 2012).

This contribution benefits from the results of classical diagenetic studies (e.g. Morad et al. 2012) and outcomes of $\mu$ CT-PNM reactive and transport simulations (e.g. De Boever et al. 2012). It does not illustrate a complete endeavour of reservoir characterization and rock-typing of an oilfield (with essential down- and up-scaling solutions). This study attempts instead to provide insights on the use of two independent workflows to better quantify the diagenetic impacts on some of the world best carbonate reservoirs (namely the Jurassic Arab Formation of Abu Dhabi, U.A.E.), a compulsory step to proceed towards numerical modelling.

\section{MARINE EVAPORATIVE DOLOMITIZATION MODEL}

The main interest in dolostones comes from the fact that they include about $50 \%$ of the known carbonate oil and gas reservoirs. The Ghawar field (Saudi Arabia), which contains one-eighth of the world proven reserves, taps the Permian Khuff and Jurassic Arab, shallow shelf/ramp limestone and dolostone reservoirs. It is primarily the permeability enhancement (through the re-distribution of porosities upon dissolution-reprecipitation) during dolomitization that increases reservoir capacities (Lucia 1999), especially when this occurs during early diagenesis (i.e. before considerable burial).

Dolomitization 'models' are concepts based on a set of field, petrographic and geochemical characteristics. Ascribing a certain 'model' for a dolostone lithosome allows geoscientists to assume and predict qualitatively other unknown parameters, by analogy to similar dolostones classified through the same conceptual model and where such parameters are known. Hence, one can predict the dimensions, distributions and reservoir quality of dolostones according to which 'model' they belong to. From a conceptual point of view, various dolomitization models have been proposed to date, covering many diagenetic environments (Fig. 2) and involving fluids with a wide range of chemical composition (e.g. reflux, sabkha, burial, seawater, hydrothermal, microbial; Adams \& Rhodes 1960; Butler 1969; Folk \& Land 1975; Mattes \& Mountjoy 1980; Saller 1984; Simms 1984; Ward \& Halley 1985; Humphrey 1988; Machel \& Burton 1994; Muchez \& Viaene 1994; Vasconcelos \& McKenzie 1997; Wright 1997; Davies \& Smith 2006; Gasparrini et al. 2006; Swennen et al. 2012). More recently, Merino \& Canals (2011) proposed a new dynamic model for dolomitization, advocating dolomite-growth-driven pressure solution of the limestone host, which may account for many of previously termed 'burial dolostones'.

The processes that are invoked for sabkha and reflux dolomitization models are believed to have occurred in near-surface to shallow burial diagenetic environments 


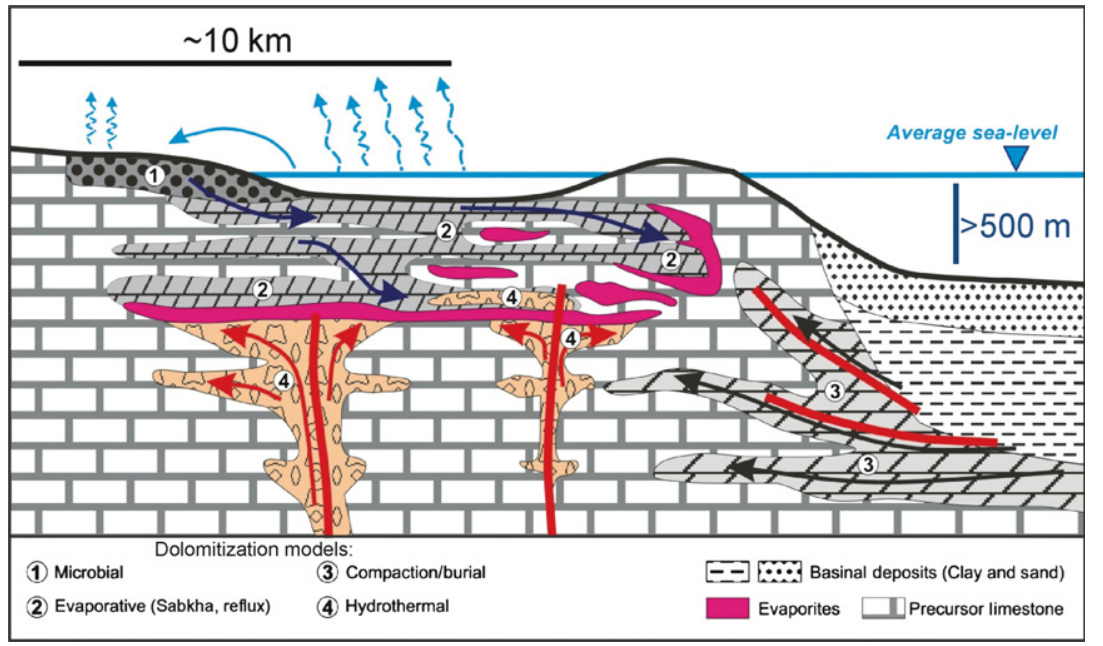

Fig. 2. Examples of conceptual dolomitization models (1: microbial; 2: evaporative marine related - sabkha and reflux; 3 : burial and compaction-related; and 4: fracture-related high temperature - HTD). The expected fluid flow pathways are indicated with arrows (after various authors, for more details see text). (e.g. Adams \& Rhodes 1960; Butler 1969; Folk \& Land 1975; Morad et al. 2012). Demonstrating that evaporative sabkha and shallow burial seepage reflux models prevail for a certain dolostone body is often based on, at least, two considerations (e.g. Fontana et al. 2010): (i) cross-cutting relationships suggesting that dolomitization occurred before burial pressure-dissolution (bed-parallel stylolites) and (ii) $\mathrm{O}, \mathrm{C}$ and $\mathrm{Sr}$ isotopic values of dolostones and associated cements within the range of isotopic signatures typical of carbonates precipitating from evaporated seawater (Veizer et al. 1999).

The Jurassic Arab Formation in the Middle East, which is the case study used for this contribution, is known to have been affected by marine-related sabkha and reflux dolomitization (cf. Swart et al. 2005; Morad et al. 2012). Here, the association of anhydrite/gypsum beds, nodules and cements with dolostones also suggests that dolomitization occurred through increased salinity and density of seawater (Adams \& Rhodes 1960; Machel 1986; Kaufman 1994; Meyer et al. 1996; Jones \& Xiao 2005; Swart et al. 2005). A seepage reflux mechanism has been invoked for pumping such evaporative brines in the underlying limestones of the Arab reservoirs offshore Abu Dhabi and causing the pervasive dolomitization, which affects sediments in the subtidal, the shoal and the lowstand wedge (Morad et al. 2012). Subsequent dolomite stabilization could be accelerated by the removal of calcium and sulphate ions (through the precipitation of the above mentioned sulphates), which may have an inhibiting effect on dolomite formation (Morrow \& Ricketts 1988; Slaughter \& Hill 1991). Accordingly, the deduced early dolomitization is associated with anhydrite cementation that obviously decreases the bulk rock porosity. The secondary porosity enhancement prevailed, subsequently, during late diagenesis, when such anhydrite cement was considerably dissolved (cf. Morad et al. 2012).

\section{METHODOLOGY}

\section{Petrography}

Petrographic analyses were performed on 168 thin sections of limestone and dolostones from Arab D and C reservoirs in an oilfield, offshore Abu Dhabi (size of the field is around $25 \times 30 \mathrm{~km}$ ). Thin sections were stained with Alizarin Red $S$ and potassium ferricyanide to distinguish rapidly ferroan from nonferroan dolomite and calcite (Dickson 1966). Petrographic investigation was undertaken using conventional (e.g. Nikon ECLIPSE LV 100POL) and cathodoluminescence (CL) microscopic techniques (e.g. Cathodyne OPEA; operating conditions $12-17 \mathrm{kV}$ gun potential, 350-600 $\mu \mathrm{A}$ beam current). Scanning electron microscope (SEM) equipped with energy dispersive spectrometer (EDS) was used for detailed observations and qualitative chemical analyses (operation conditions: $12 \mathrm{kV}$ beam voltage, $10 \mathrm{~mm}$ working distance, WD).

Local Oil Companies disposed petrographic and petrophysical databases for oil and gas fields that are presented on Microsoft Excel sheets. Such databases contain petrographic data (e.g. lithology, texture, cement type, porosity) of thousands of thin sections from the exploration and production wells, as well as porosity and permeability values. For this contribution, a similar petrographic and petrophysical database including data from 13 wells intercepting the investigated reservoirs (Arab D and C) in the oilfield (offshore Abu Dhabi) was available.

\section{Mapping and statistical tools}

EasyTrace $^{\mathrm{TM}}$ version 4.3 (2009), which is a registered trademark of IFP Energies nouvelles, was used to analyse the petrographic and petrophysical database derived from 13 wells (about 1300 thin sections), as previously mentioned. EasyTrace is a multidisciplinary data processing and 
editing tool, featuring advanced spreadsheets and a wide range of functionalities. The software creates multigraphs, correlation graphs, histograms and X-Y cross-plots, which were useful to analyse the distribution and relationship between sedimentary and diagenetic phases and reservoir properties in the investigated oilfield.

ArcGIS (version 9) was utilized to produce proportional distribution maps of the prevailing lithologies, major diagenetic phases and petrophysical parameters, at the field scale. These maps are based on the petrographical and petrophysical database previously constructed and analysed with EasyTrace at the scale of individual wells or a group of wells. In ArcMap GIS, 'Spatial Analyst' was the function used to produce the maps. Here, the Inverse Distance Weighted (IDW) interpolation method was used to fill the area between the wells and to construct a variety of maps across the investigated oilfield (e.g. lithology, rock texture, cement type, porosity). The units that are associated with the data-featured on these maps are of two different types: (i) numerical values (e.g. dolomite \%, permeability values) or (ii) ranges of abundance classes [absent, rare, common, abundant] (e.g. syntaxial calcite overgrowth cement, porosity types).

\section{Micro-Computed Tomography $(\mu-\mathrm{CT})$ and Pore Network Modelling (PNM)}

A 3D view of one dolostone sample plug of the Arab C Member was acquired using a Nanotom high-resolution $\mathrm{X}$-ray $\mu$-CT from PHOENIX X-Ray, installed at IFP Energies nouvelles. A first scan of a 23-mm-diameter plug shows a rather homogeneous fabric. Based on this scan, the location for a miniplug of $5 \mathrm{~mm}$ diameter was decided. The miniplug was the study object for phase quantification and the reconstruction of an equivalent pore network used for the numerical simulation of transport properties, that is, Pore Network Modelling (PNM). X-ray computed (micro) tomography $(\mu-\mathrm{CT})$ is a well-known tool to image and quantify rock constituents (Long et al. 2009) and describe in detail 3D pore network geometries (Arns et al. 2005; Youssef et al. 2007a). The $\mu$-CT based complex pore structure reconstructions can be used in available numerical tools that allow simulating the petrophysical rock properties (Arns et al. 2004; Knackstedt et al. 2004, 2006; Youssef et al. 2007b, 2008; Al-Kharusi \& Blunt 2008).

Parameters during acquisition of $\mu$-CT images of the miniplug are a rotation step of $0.2^{\circ}$, a tube voltage of $90 \mathrm{kV}$ and a current of $170 \mu \mathrm{A}$. The detector is a Hamamatsu flat detector $(110 \mathrm{~mm} \times 110 \mathrm{~mm})$ made up of a $2304 \times 2304$ pixels grid, with a step of $50 \mu \mathrm{m}$. For the studied sample of the Arab C Member, the detector was shifted along the projection plan to create a virtual detector of $2304 \times 4608$ pixels (pxls), allowing a larger field of view. The source-object distance is $6.2 \mathrm{~mm}$, and the source-detector distance
$200 \mathrm{~mm}$. With this set up, a resolution of $1.5 \mu \mathrm{m}$ is obtained. The reconstruction (PHOENIX algorithm) uses a cone-beam Feldkamp algorithm. The beam hardening effect is corrected using a metal Cu-filter $(0.1 \mathrm{~mm})$ and a mathematical correction during the reconstruction process.

The reconstructed volume is visualized and analysed using the Avizo software package (version 6.2, VSG, France) and Image J software 1.44. The workflow for quantification and creation of an equivalent network of pores and pore throats starts with isolating the resolved pore space and different mineral phases for quantification. Noise is reduced and image contrast increased, by stretching the histogram and by application of a mean filter. Phase separation or image segmentation is performed based on minima in the gray level histogram and improved by morphological operators (growing, shrinking and removal of islands). The volumetric percentages for each phase are compared with results of He-porosimetry for porosity and quantitative XRD measurements for the crystalline, mineral phases. This step is followed by the reconstruction of an 'equivalent pore network' through a skeleton extraction step and a pore space partitioning step, resulting in a pore volume consisting of different pores, divided by pore throats. Following the pore space partitioning step, a connection matrix is built which is used to numerically simulate transport properties (Pore Network Modelling). Here, the focus is on mercury intrusion capillary pressure (MICP) and the pore network permeability. The procedure and main steps of the modelling, using an in-house developed code, are explained by Youssef et al. (2007b) and Laroche et al. (2001).

\section{PETROGRAPHIC ATTRIBUTES}

\section{Lithofacies of the Arab D and Arab C Members}

The Jurassic carbonate-evaporite sequence in the Arabian Gulf is represented by the Arab Formation (Kimmeridgian -Tithonian) and the overlying Hith Formation (Tithonian; Alsharhahn \& Whittle 1995). Based on lithology, the Arab Formation is subdivided into four members (from bottom to top): Arab D, C, B and A (Fig. 3; Alsharhahn \& Whittle 1995). These members reflect cyclic deposition in a progressively shallowing marginal marine shelf to sabkha environment of a wide ramp. Arab C and D Members include the main reservoirs of the Arab Formation (Cantrell \& Hagerty 2003; Lindsay et al. 2006), which are overlain by progressively increasing evaporitic lithologies (Arab $\mathrm{A}$ and $\mathrm{B}$ Members) culminating in the overlying Hith Formation, which is known as a regional evaporitic seal (Alsharhahn 1989).

Chief petrographic aspects as well as a constructed generalized paragenesis for the Arab D and C Members, based on well-data from an oilfield offshore Abu Dhabi (U.A.E.), have been previously published (see Morad et al. 2012; 


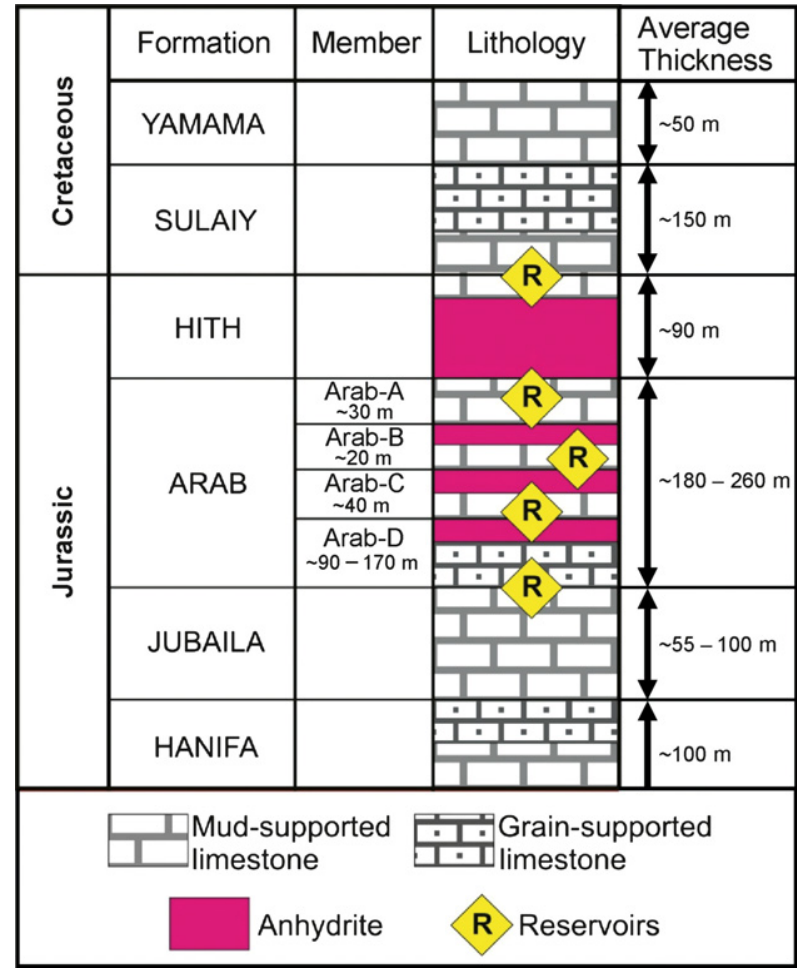

Fig. 3. Generalized Late Jurassic stratigraphy and lithologies in the United Arab Emirates (U.A.E.), including the Arab and Hith Formations and reservoirs (modified from Lindsay et al. 2006).

and references therein). Here, we highlight those aspects related to the porosity evolution throughout the paragenesis, and which are adapted for further quantification, following the two workflows detailed in this article.

The main lithologies of the Arab D and C Members are limestones, dolostones and anhydrites. Limestones prevail in the Arab D strata (bulk rock generally vary from 60 to $100 \%$ limestone), still including some dolostone interbeds. The limestone-dominant Arab D transgressive systems tract passes upwards to dolostone- and anhydrite-dominant Arab C highstand systems tract. As the Arab Formation was deposited in lagoon, shoal and outer ramp depositional environments (Morad et al. 2012), original lateral textural heterogeneities and subsequent diagenesis patterns also exist. For instance, dolomitized Arab D grainstones are more frequent in lagoon and shoal facies than in outer ramp facies (Fig. 4).

\section{Paragenesis of the Arab D and Arab C Members}

Upon early dissolution of allochems and aragonite stabilization, the primary and secondary pores in some grainstone, which are considered as the best reservoirs, have been partially cemented by syntaxial overgrowth and equant calcite (Morad et al. 2012). These cements may have supported the framework grains and prevented exten- sive compaction, thus preserving primary interparticle porosity during burial (compare Fig. 5A,B: $30-35 \%$ vs. 0-15\% bulk sample porosity). During shallow burial, further phases of dissolution of the calcite cements and the leaching of allochems resulted in enhanced secondary porosity, in particular of vuggy and mouldic pore types (Fig. 5C, D). Calcite cementation and leaching events appear to have had significant impact on the high reservoir quality of the upper part of the Arab D (cf. Grötsch et al. 2003).

Fabric-destructive dolomitization (D2b and DC2, replacement and cement dolomite, respectively) seems to have reduced the porosity (ca. $10 \%$; Fig. $5 \mathrm{E}$ ), both in grain- and in-mud-supported rock textures. Subsequent dissolution has produced considerable intercrystalline (Fig. 5F) and vuggy porosity $(25-30 \%)$ in dolomitized mudstone and grainstones, restoring moderately the overall rock porosity. Nevertheless, this enhanced secondary porosity was, successively, partly or completely occluded by anhydrite and minor amounts of celestine cements (AC2) (Fig. 6A,B). The co-existence of anhydrite and celestine in an interpreted burial setting may suggest that the formation of the celestine was due to burial alteration of preexisting sulphates coinciding with seepage reflux of Sr-rich fluids having relatively high salinity (Hanor 2004). Alternatively, celestine could have been a by-product of the transformation of Sr-rich gypsum to anhydrite during burial (Hanor 2004). Upon burial dissolution of this anhydrite cement, the secondary porosity was enhanced before being affected, at least locally, by the precipitation of burial anhydrite $(\mathrm{A} 3 ; 5-10 \%)$ and calcite cements (C3; 5-20\%) (Fig. 6C,D).

The generalized paragenetic sequence of the investigated Arab reservoir rocks is presented in Figure 7. Similarly to the overlying Arab C, the Arab D Member also contains three types of dolomites: (i) planar euhedral or subhedral dolomicrite (crystal size $<15 \mu \mathrm{m}$ ) typical of peritidal environments [Dl]; (ii) planar (euhedral or subhedral) or nonplanar (anhedral) dolomicrospar (crystal size 20-100 $\mu \mathrm{m}$ ), which can be fabric-preserving or fabric-destructive [D2]; (iii) recrystallized planar euhedral dolomicrospars (20$100 \mu \mathrm{m}$ ) and dolospars (crystals size >100 $\mu \mathrm{m}$ ) [D3] formed during burial. Three different anhydrites are also distinguished as the following: (i) those associated to nodular chicken-wire structures typical of sabkha depositional environment [Al]; (ii) blocky and pervasive crystals that precipitated during shallow burial with crystal size $<60 \mu \mathrm{m}$ [A2]; and (iii) felted $(<500 \mu \mathrm{m})$ and lath $(>500 \mu \mathrm{m})$ crystals, which fill fractures formed during burial [A3].

\section{QUANTIFICATION OF DIAGENETIC PHASES AND POROSITY}

Grain-supported limestone textures appear to be dominant throughout the Arab D Member, where the anhydrite 


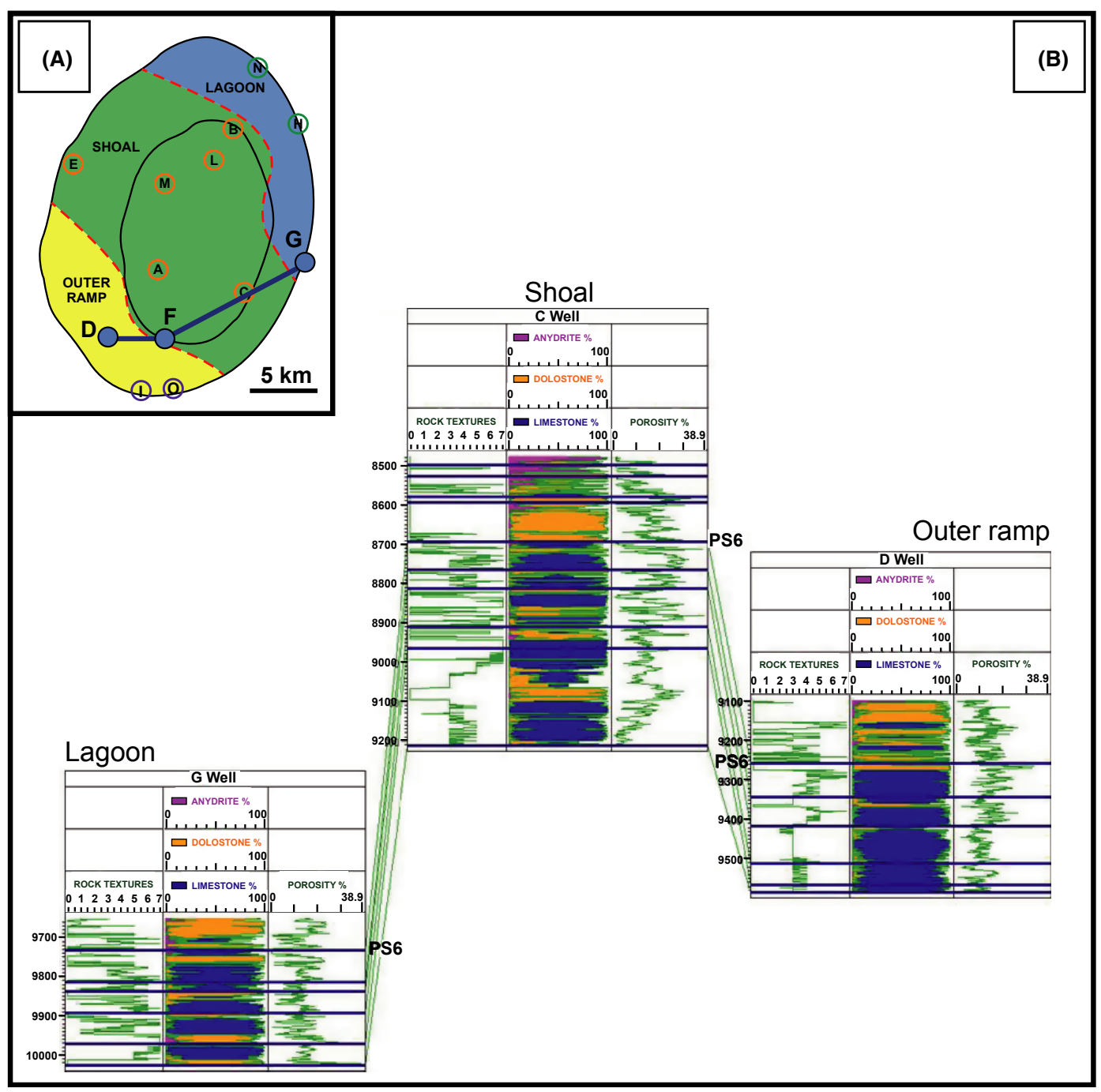

Fig. 4. (A) Schematic map showing the investigated oil field and associated depositional environments - key wells are also indicated. (B) Correlation crosssections (constructed by EasyTrace software) showing the distribution of main rock textures, lithologies and porosity across the depositional environments (lagoon to outer ramp through shoal; northeast to southwest of the studied oil field). Limestone, dolomite and anhydrite are coloured in blue, orange and pink, respectively. For the rock textures legend, see Fig. 9.

cement does not exceed $10 \%$ and syntaxial calcite overgrowth cement (SCO) is common to abundant (Fig. 8). Porosity and permeability values are relatively high (from 10 to $30 \%$ and from 3 to $1000 \mathrm{mD}$, respectively). Such parameters are quite different with respect to the grainstones of the overlying Arab C Member. The grainstones are partially dolomitized and anhydrite content may reach $45 \%$, with the associated flow properties being generally lower than those observed in the Arab D Member (ca. porosity around $10 \%$ and permeability not exceeding $300 \mathrm{mD}$ ).

Dolomitization appears to increase upwards and affects mostly the Arab C Member, which also shows increasing anhydrite contents (cf. Fig. 4). The highest porosity values (ca. 20-32\%) occur in samples that are either slightly
(1-30\%) or pervasively $(90-100 \%)$ dolomitized. Anhydrite and dolomite cements may reach up to $15 \%$ of the bulk rock. Nevertheless, the vug-filling dolomite cement is generally rare or absent. There is no clear relationship between the dolomite and anhydrite cements and secondary porosity, as in some cases porosity is observed to be preserved even if cements are common.

\section{Proportional distribution mapping}

Proportional distribution maps were produced for Arab D and Arab C Members through the investigated oilfield (see Methodology). The maps show the averages of the following parameters: lithologies (limestone, dolomite and anhydrite), cements (e.g. dolomite, anhydrite, syntaxial calcite 

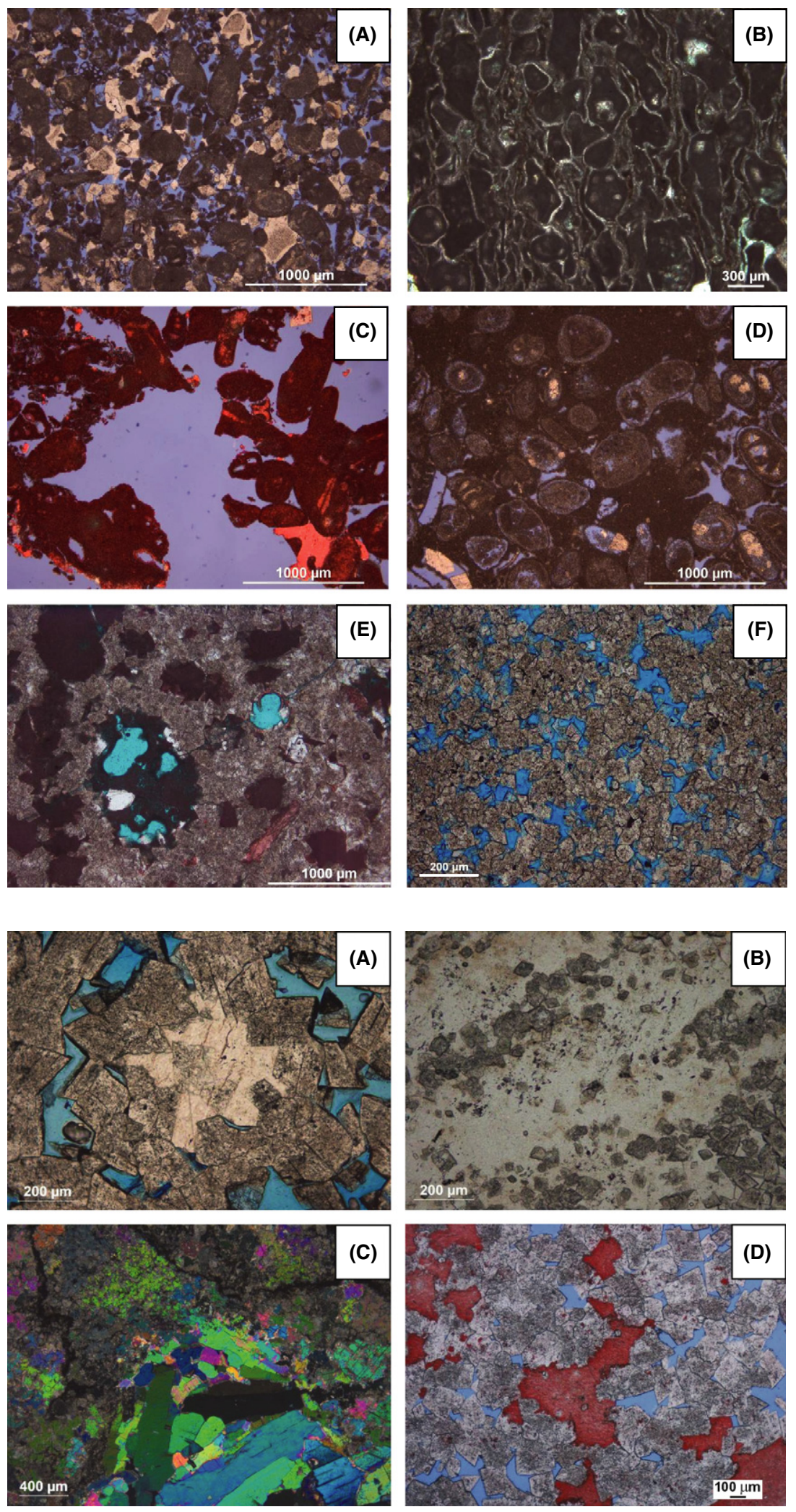

Fig. 5. Petrographic characteristics of some diagenetic phases in limestones and dolostones (investigated oilfield; UAE), plane-polarized transmitted light photomicrographs: (A) peloidal grainstone facies, with significant syntaxial overgrowth cement and consequent high interparticle porosity; (B) highly compacted peloidal grainstone facies, where neither the syntaxial cement nor the related porosity occur; (C) considerable vuggy porosity after the leaching of the allochems; (D) Dissolved ooids/peloids, mouldic porosity; (E) grainstones almost completely dolomitized with subsequent reduction in porosity; (F) high intercrystalline porosity in planar euhedral dolomicrospar.

Fig. 6. Petrographic characteristics of some diagenetic phases in limestones and dolostones (investigated oilfield; UAE), transmitted light photomicrographs: (A) intercrystalline porosity within a mosaic, planar euhedral dolomite, partly filled by anhydrite cement (A2), plane-polarized; (B) secondary porosity completely filled by anhydrite cement (A2), plane-polarized; (C) secondary porosity filled by gypsum and anhydrite (A3), cross-polarized; (D) intercrystalline porosity partly occluded by the late calcite (C3), planepolarized.

overgrowth and equant calcite), porosity types (e.g. interparticle, intercrystalline, vuggy), fluid porosity and permeability.
The general trend of depositional environments remained quite similar for Arab D and C Members, with 'lagoonshoal-outer ramp' configuration oriented from north/ 


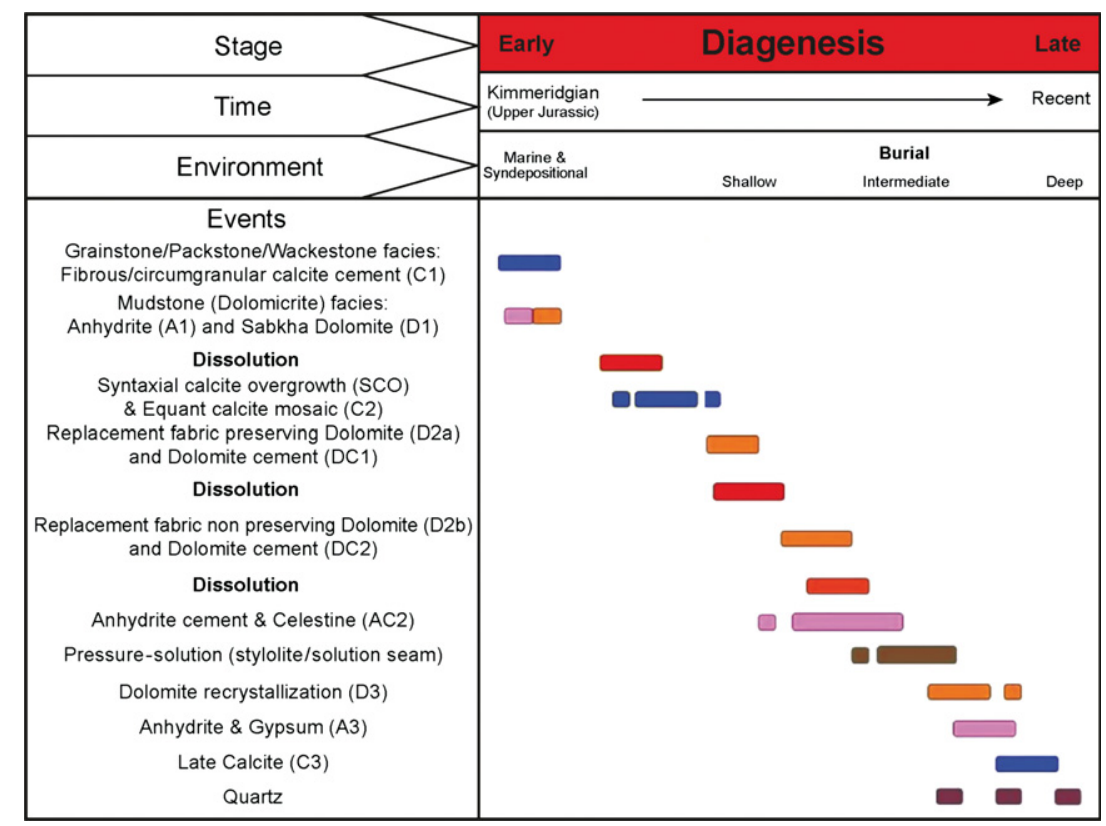

Fig. 7. Generalized paragenesis for the Arab Formation (Abu Dhabi - UAE). For more details, refer to Morad et al. (2012). Blue for calcite, pink for anhydrite, beige/orange for dolomite, purple for quartz, red for dissolution and brown for stylolites.

(A)

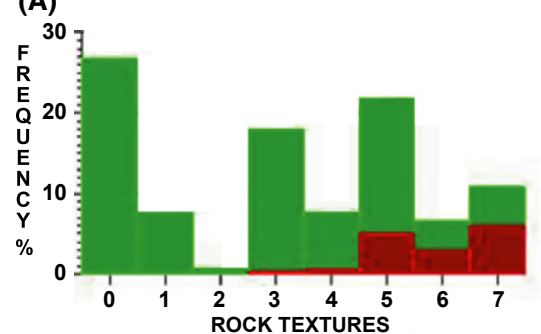

(D)

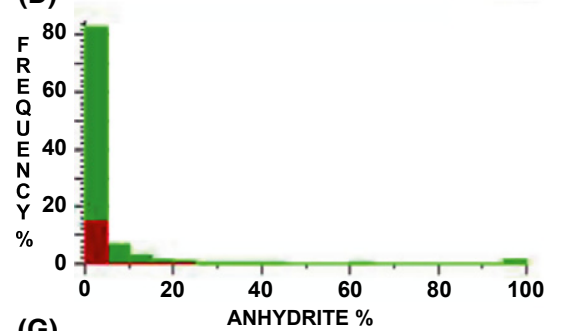

(G)

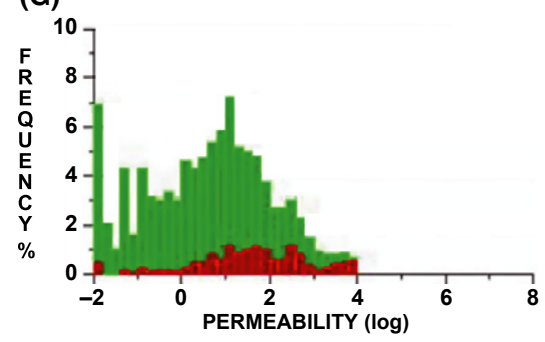

(B)

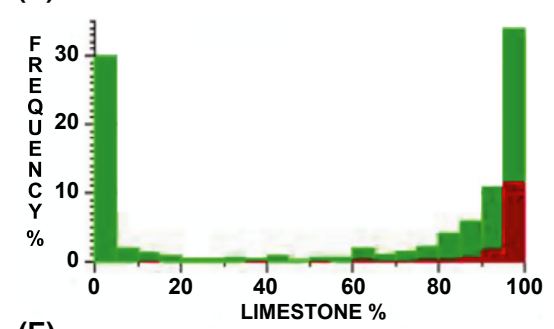

(E)

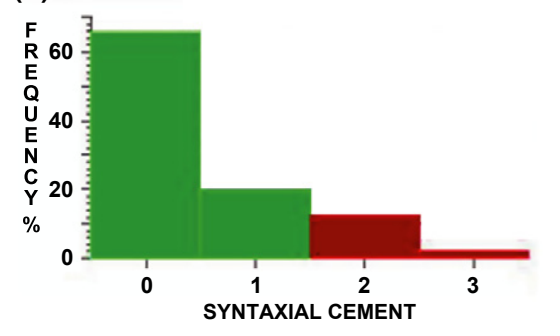

(C)

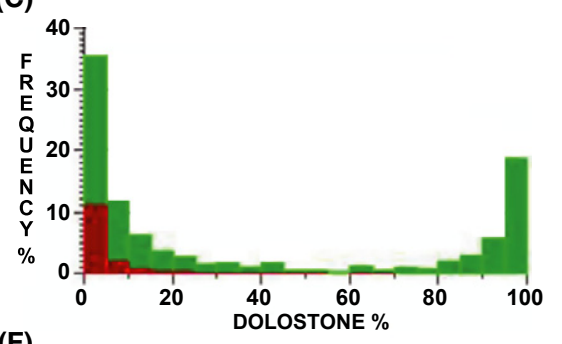

(F)

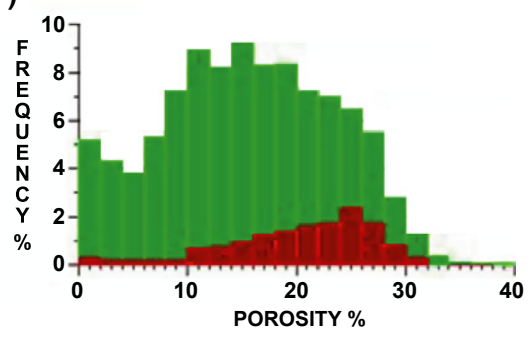

LEGEND

\section{SYNTAXIAL CEMENT}

0 : Absent

1: Rare

2: Common

3: Abundant

2: Mud-Wackestone

3: Wackestone

4: Wack-Packstone

5: Packstone

6: Pack-Grainstone

7: Grainstone

Fig. 8. Statistical analyses of the Arab D Member well-data-featured on histograms and including (A) Rock textures; (B) Limestone \%; (C) Dolostone \%; (D) Anhydrite \%; (E) Syntaxial calcite overgrowth (SCO) abundance; (F) fluid porosity; (G) permeability. Note that the populations of data corresponding to [common] and [abundant] SCO cement are coloured in red. 

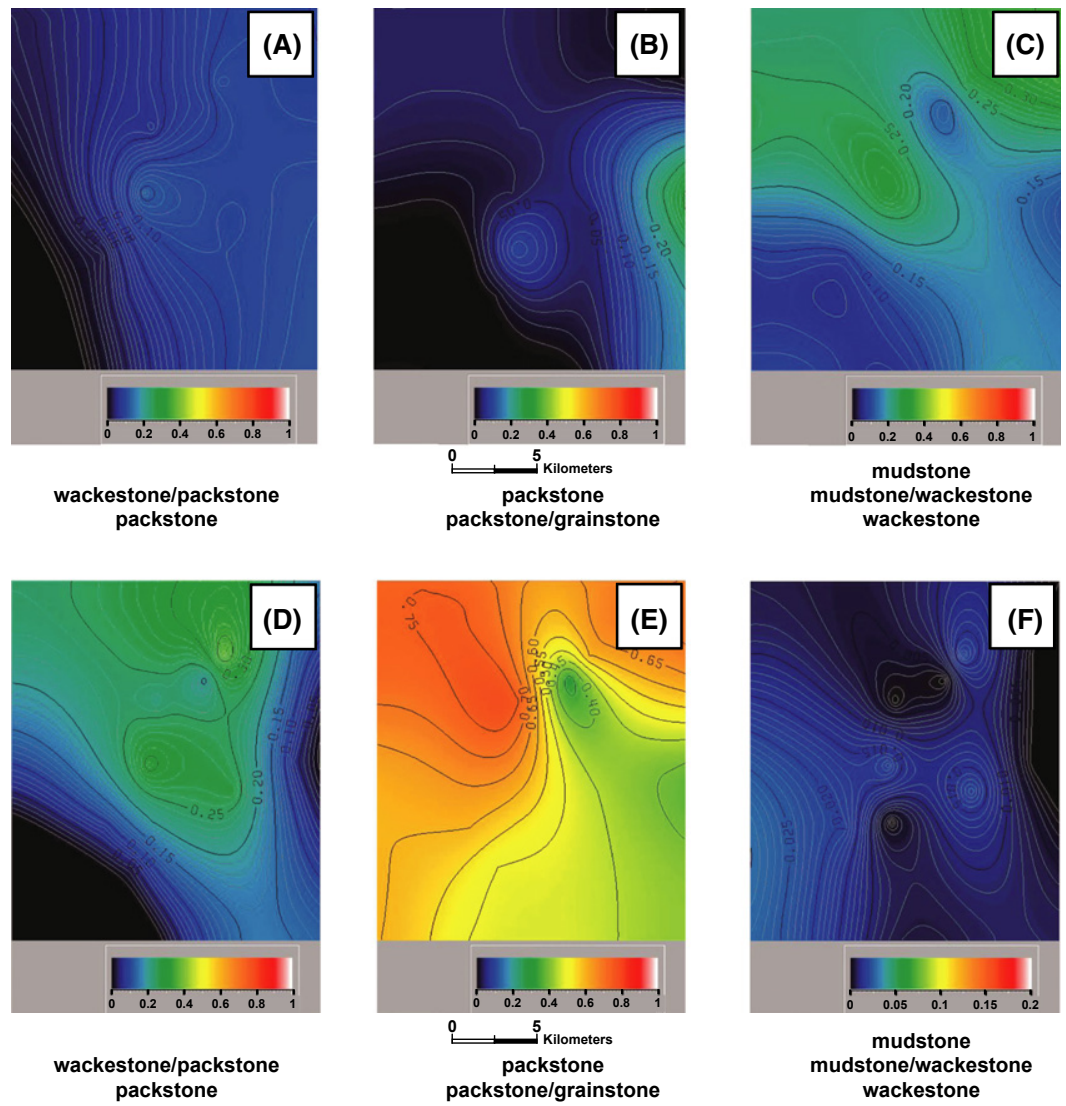

Fig. 9. 2D Proportional maps showing the dolostone (A: Wackestone-Packstone; B: Packstone-Grainstone; C: Mudstone-Wackestone) and the relative abundance of the syntaxial calcite overgrowth (SCO) cement (D: WackestonePackstone; E: Packstone-Grainstone; F: Mudstone-Wackestone) in the Arab D reservoirs of the investigated oilfield offshore Abu Dhabi (UAE). Average depth of the map ranges between 3000 and $4000 \mathrm{~m}$. northeast to south/southwest across the oilfield (see also Morad et al. 2012). The Arab D Member includes limestone ranging from 0 to $75 \%$ across the investigated oil field. For most of the grain-supported textures (packstone to grainstone), which are common in shoal facies, the dolomite content does not exceed 20\% (Figs 8, 9A,B). An eastward increase in dolomitization appears particularly clear on the map showing the dolomite percentage for the grainstones (Fig. 9B). The mud-supported textures show relatively higher dolomite content (up to $40 \%$ ) especially in the northern (more precisely, north-eastern) part of the field (Fig. 9C). The maps showing the distribution of the syntaxial calcite overgrowth cement (SCO) in the prevailing limestone rock textures (wacke-packstone, pack-grainstone and wacke-mudstone) throughout the field reveal varying patterns (Fig. 9D,E and F). The central and northern parts of the field (where lagoon and shoal facies prevail) include moderate amounts of SCO in wacke-packstones (Fig. 9D), whereas the most abundant SCO is found in the pack-grainstones and particularly in the north-western part of the field (Fig. 9E). The mud-supported textures show almost no presence of SCO cements (Fig. 9F).

In the Arab D Member, the maximum values for interparticle porosity are found in the shoal facies that are located in the central part of the oilfield. In the same locations, the lithology is chiefly limestone, the rock textures are mainly grain-supported and higher amounts of SCO cements are encountered. The highest average values of vuggy porosity coincide with a partially dolomitized area (also featuring considerable amounts of anhydrite). No systematic distributions of interparticle and vuggy porosity were observed in the investigated database.

Porosity and permeability 2D proportional distribution maps for Arab D and C Members of the investigated oilfield are presented in Fig. 10. Here, the displayed porosity and permeability refer to the values averaged over the whole thicknesses of the Arab D and C Members, respectively. The total average porosity in the Arab $\mathrm{D}$ ranges between 1.5 and $19.5 \%$ (Fig. 10A). The highest values occur in the central part of the field. The permeability varies from a few to $100 \mathrm{mD}$ (or - 1.2 to 2.0 Log-Permeability; Fig. 10B), with the maximum being located also in the central part of the field. The high average values of the total porosity and permeability appear to relate to grainsupported limestones with considerable amount of SCO cements and relatively high interparticle porosity in the central-northern part of the oilfield. Relatively, lower permeability values coincide with dolostones in the north-eastern and eastern zones of the investigated area (Fig. 10B). The highest anhydrite contents in the Arab D Member are found in the north-eastern part of the oilfield, where the prevailing depositional environment is lagoonal. 

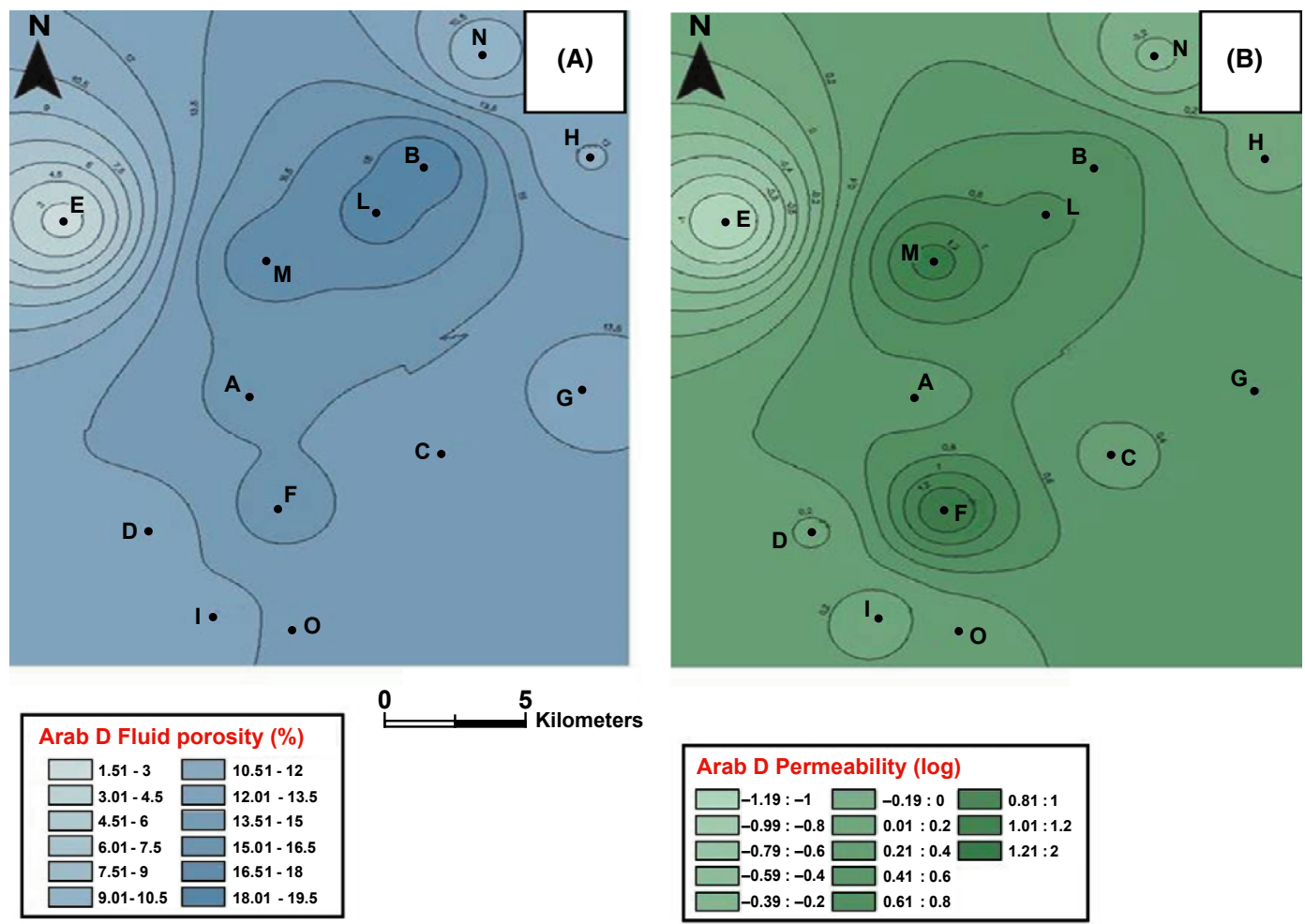

Kilometers
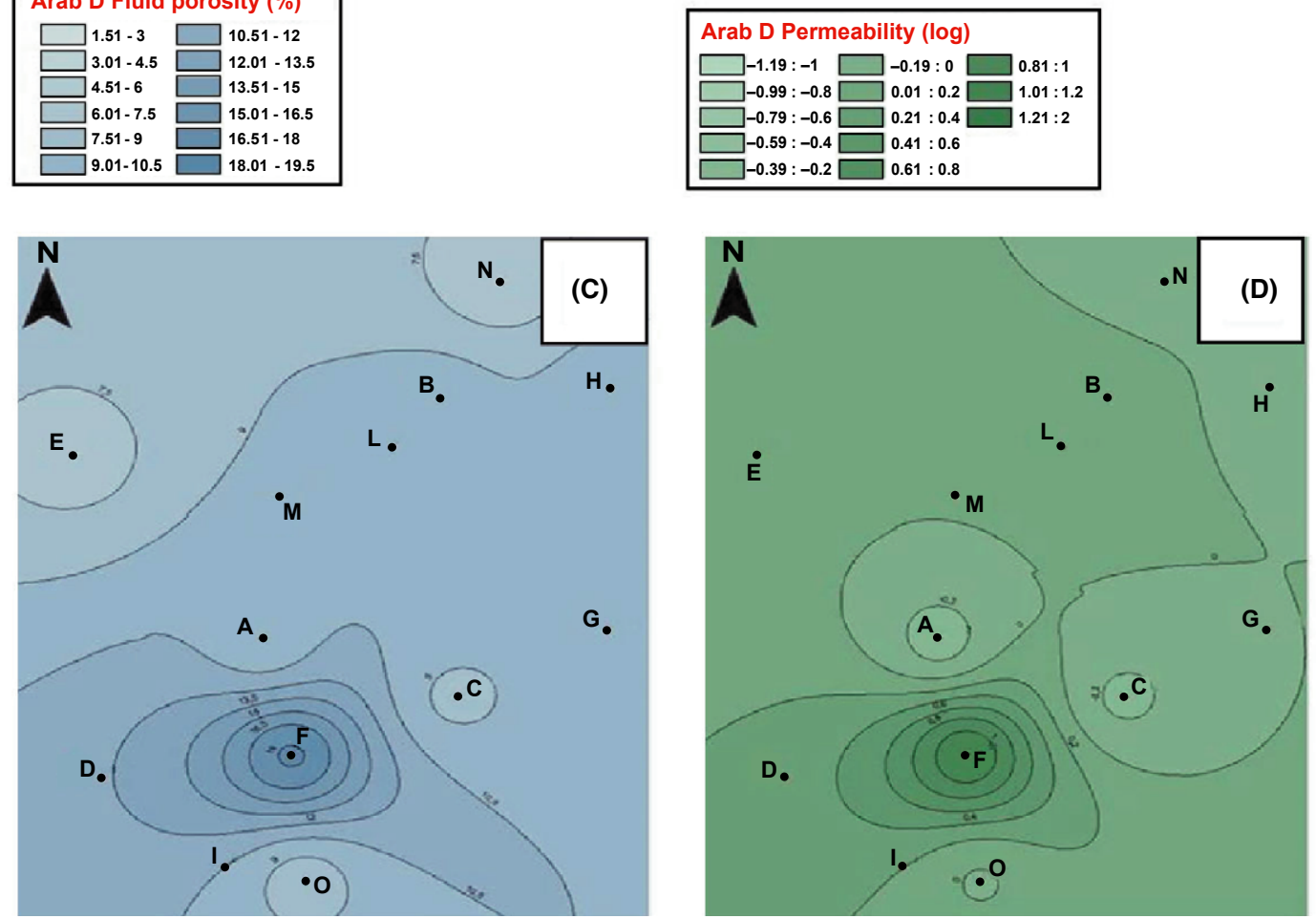

Fig. 10. $2 D$ proportional maps showing the distribution of porosity percentage ( $A, B)$ and Log-permeability $(C, D)$ values in the Arab $D$ and Arab $C$ reservoirs of the investigated oil field offshore Abu Dhabi (UAE). Average depth of the map ranges from 3000 to $4000 \mathrm{~m}$.

Dolostones dominate the Arab C Member throughout the study area with average values ranging between 50 and 95\% (mainly in the central and south-western parts of the field). The total average porosity values in the Arab C Member are found to be between 6 and 19.5\%. The highest values are found in the south-western part of the field, whereas the low values are distributed in the north and north-west (Fig. 10C). The average permeability ranges from a few to $16 \mathrm{mD}$ (or - 0.4 to 1.2 Log-Permeability); and the highest values occur in the south-western zone (Fig. 10D), whereas the lowest values are in the central and northeastern parts where the land-proximal lagoonal depositional environment prevails and anhydrite is more common to abundant.

\section{$\mu$-CT 3D Visualization of Arab C reservoir rocks}

The Arab C dolostones present further complexities with respect to their reservoir properties, as these dolostones are 
inherently associated with anhydrite. Hence, a typical Arab C dolostone sample plug was studied in more detail for the $3 \mathrm{D}$ structure of its pore network and mineral phases (Fig. 11). It consists of subhedral to euhedral dolomite rhombs, with intercrystalline microporosity and minor mouldic and vuggy porosity (cf. Lønøy 2006). The present porosity makes up $18.5 \%$, as determined with $\mathrm{He}$-porosimetry (Table 1). Locally, a transparent, euhedral dolomite cement occurs as rims around the cloudy, inclusion-rich replacement dolomite or as euhedral rhombs in intercrystalline porosity. In some limited cases, anhydrite crystals seem to replace dolomite rhombs.

Classical petrographical techniques provide a detailed view of the diagenetic phases and history, but limit the observations to two dimensions. $\mu$-CT based $3 \mathrm{D}$ visualization of a rock sample allows understanding the spatial relationship (on a plug scale) of the different diagenetic phases and permits a more adequate quantification of the pore space and petrophysical properties. We integrate quantitative XRD results for the identification and quantification of mineral phases with $\mu$-CT plug images and petrophysical measurements (porosity, permeability, MICP) to optimally characterize and quantify the rock composition and pore structure.

Two adjacent volumes of $1000 \times 1000 \times 1000$ pixels are extracted from the miniplug $\mu$-CT image and appended to form a basic volume of $6.7 \mathrm{~mm}^{3}$ with a voxel resolution of $1.5 \mu \mathrm{m}^{3}$. The porosity percentage is calculated for several volumes of increasing size indicating a representative
Table $1 \mu$-CT quantification results for the different phases observed and measurements of He-porosimetry and XRD. After De Boever et al. (2012).

\begin{tabular}{llccll}
\hline & & & & & $\begin{array}{l}\text { Volume } \\
\text { percolating } \\
\text { cluster }\end{array}$ \\
\hline Vol\% & 74.8 & 8.1 & 1.1 & $16.0 \%$ & $15.3 \%$ \\
Wt\% & 88.2 & 10.0 & 1.8 & & \\
XRD wt\% & 95.4 & 3.6 & 1.0 & & \\
\hline
\end{tabular}

elementary volume (REV) of $5.4 \mathrm{~mm}^{3}$. The gray scale $\mu$-CT images show four different constituents - that is, air in pores, dolomite, anhydrite and celestine. Gray scale contrasts are successfully improved by applying a 'mean' filter. This filtering facilitates thresholding between dolomite, anhydrite and celestine, but also smoothens the image. Volumetric percentages of each phase, calculated after segmentation, are listed in Table 1 . The resolved porosity of $16 \%$ approaches the laboratory measurement (ca. $18.5 \%)$. The volumetric percentages of dolomite, anhydrite and celestine slightly differ from those experimentally measured by XRD on adjacent plug material (Table 1). The partial volume effect causes difficulties in the segmentation step; for example, where celestine and dolomite are in contact, the voxel gray value falls in the anhydrite peak of the histogram. Additional filtering (removal of 'islands') and morphological operations can only partly resolve this problem (Youssef et al. 2008).

$3 \mathrm{D}$ visualization of the rock structure shows that, in places, anhydrite occurs as irregular, nodular structures in
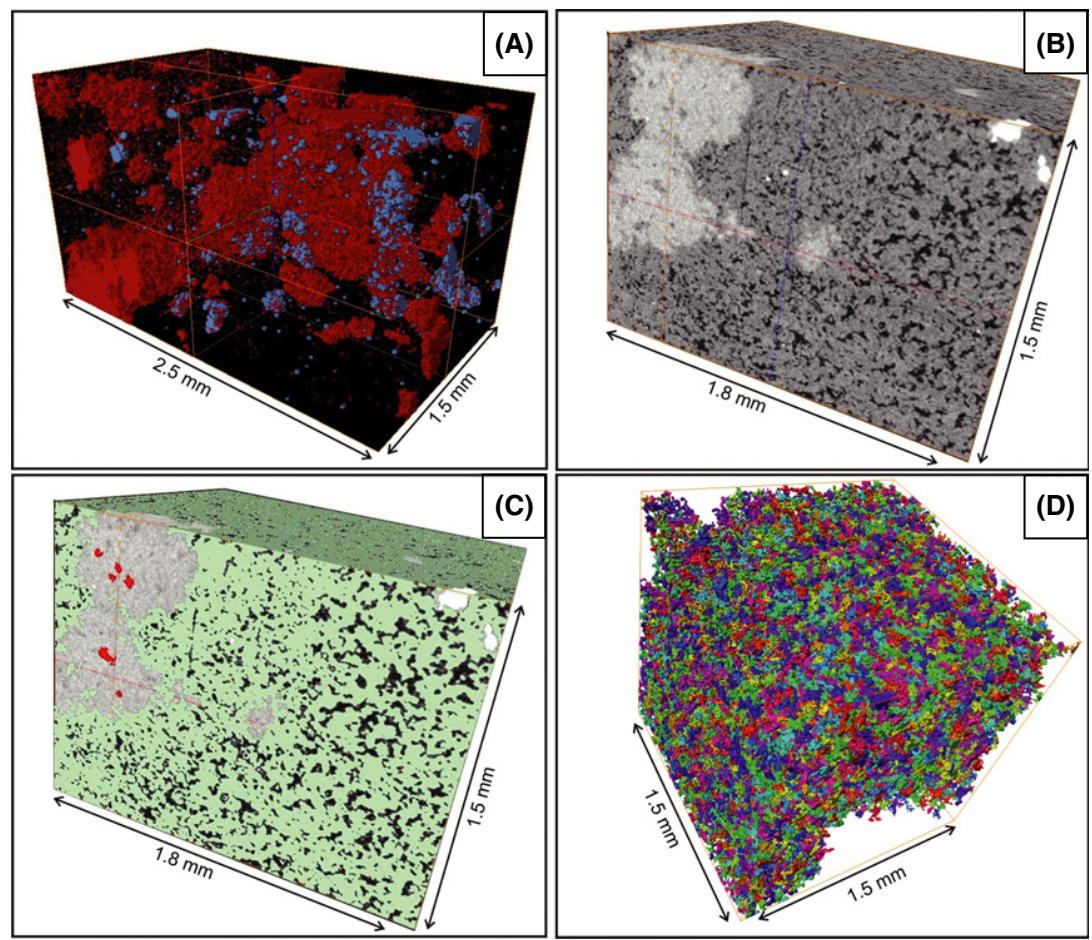

Fig. 11. (A) Subvolume of reconstructed $\mu-C T$ image showing the distribution of anhydrite (red) and celestine (blue) $(1685 \times 1000 \times 1000$ pixels). (B) 3D-gray scale view of $\mu$-CT scan $(1185 \times 1000 \times 900$ pixels $)$ - see text for details. (C) Segmented $\mu$-CT image in B showing the dolomite crystal framework in green and some remaining dolomite volumes in red entirely enclosed in an anhydrite nodule indicated in pink $(1185 \times 1000 \times 900$ pixels). (D) Partitioned pore space of the entire volume $(1000 \times 1000 \times 1000$ pixels) - see text for details. 
Fig. 12. (A) Pore-throat size distribution as measured on an equivalent sample by a mercury injection capillary pressure measurement. (B) Comparison of the simulated (PNM) and measured mercury injection capillary pressure curve.
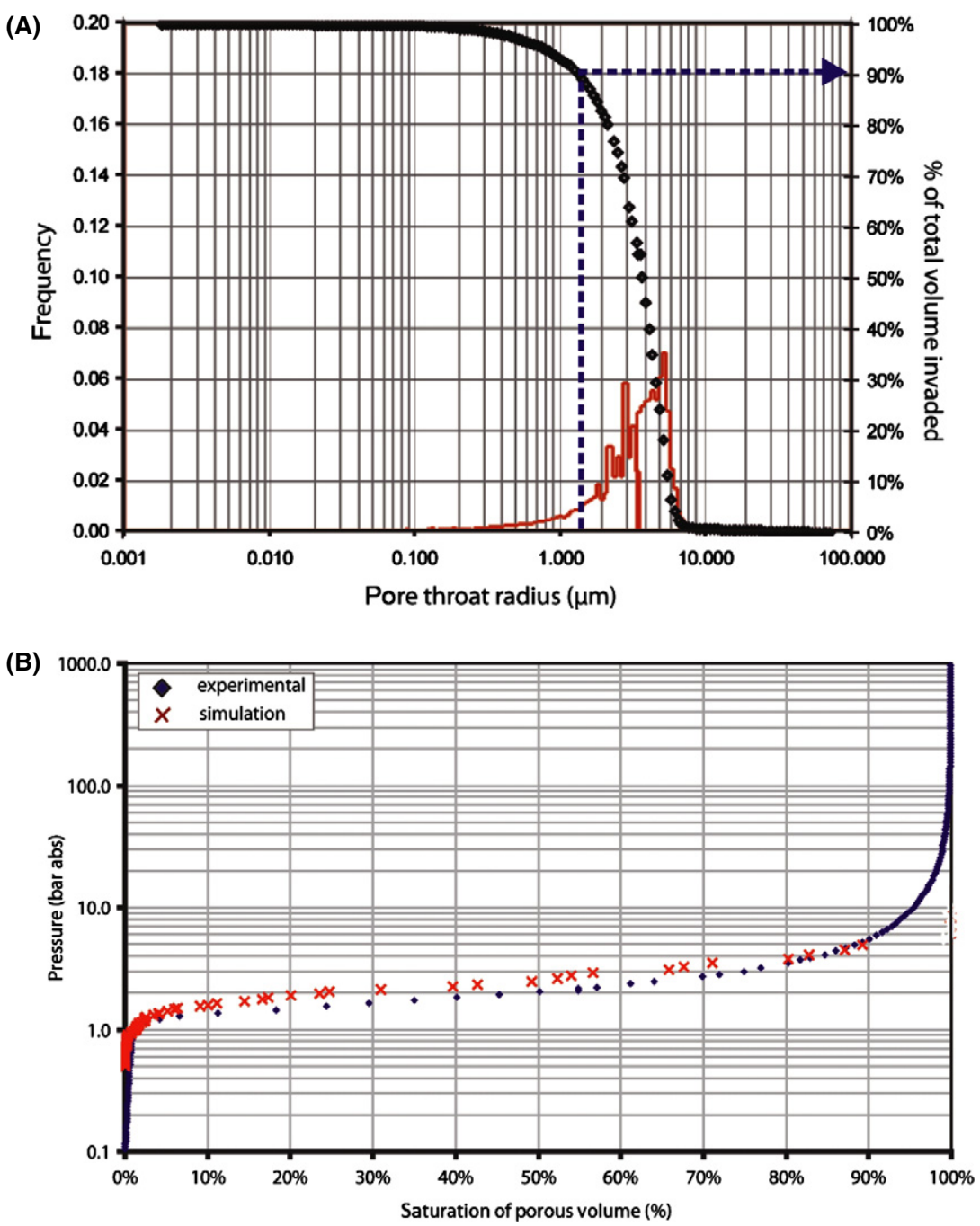

the rock fabric (Fig. 11A), blocking intercrystalline porosity and important, earlier-created vuggy porosity. Celestine marks the outer rim of anhydrite nodules or occurs as separate nodules (Fig. 11A). In 3D, anhydrite locally encloses patches of dolomite that are not connected to the dolostone crystal framework, further demonstrating its replacive nature (Fig. 11B, C).

\section{PORE NETWORK MODELLING (PNM)}

Following visualization, quantification of the pore and mineral phases and their spatial relationships in the reconstructed $3 \mathrm{D}$ rock plug image, $\mu$-CT images could be used to build an equivalent $3 \mathrm{D}$ pore network and simulate the rocks transport properties. We here focus on the present pore network, following anhydrite/celestine precipitation and replacement. This diagenetic event (diagenetic 'time step') has been crucial for the modification of the reservoir properties, as demonstrated by the previously presented/under- taken diagenetic mapping study. The 3D $\mu$-CT image of the reconstructed pore skeleton follows the isolation of the porosity by binarization and computation of a distance map, whereby each line segment marks the centre of a pore or pore throat (Youssef et al. 2007a; De Boever et al. 2012). The partitioned pore space with each colour reflecting a different pore, separated by pore throats, is shown in Figure $11 \mathrm{D}$. This is the so-called 'equivalent pore network' based on $\mu$-CT images. The pore (throat) size distribution obtained by mercury intrusion (Fig. 12A) indicates that with a $\mu$-CT resolution of $1.5 \mu \mathrm{m}, 90 \%$ of the porosity is captured and fine intercrystalline pore connections can be imaged.

The equivalent pore space (i.e. the pore space reconstructed from the $\mu$-CT image) shows an important 'percolating cluster' which constitutes $95 \%$ of the total resolved porous volume, refers to the largest porous volume and connects the sides of the studied $\mu$-CT volume. This percolating cluster is further used for the reconstruction of an equivalent $3 \mathrm{D}$ pore network for transport 
property simulations. The quality of the partitioning is validated quantitatively through the comparison between simulated and measured petrophysical properties. First, mercury injection curves are compared. The simulated curve is in good agreement with the experimental values (Fig. 12B). The entire curve could not be reproduced as the $10 \%$ of the smallest pores fall below the CT resolution. Second, the permeability value is calculated from the equivalent network yielding a value of $29.1 \mathrm{mD}$, which is very similar to the experimental value of $31.0 \mathrm{mD}$ measured on the $23 \mathrm{~mm}$ diameter core plug using a Hasseler Sleeve and nitrogen gas.

A good agreement is thus found for these transport parameters, which validates the reconstructed, equivalent pore network. It also confirms the predictability of pore network models to calculate such petrophysical properties for rather complex porous samples. This typical Arab C dolostone has been described above, and its reservoir properties have been demonstrated to be controlled by the dissolution and cementation processes of dolomite and anhydrite.

\section{DISCUSSION}

In the present study, the best reservoir rock types were identified among two rock groups: grain-supported limestone textures of the Arab D Member and dolostones of the Arab C Member. On a regional scale, the renowned high porosity and permeability of the Arab D Member occur mainly in the high-energy grainstones (cf. Murris 1980; Grötsch et al. 2003; Morad et al. 2012). The textures of limestones and dolostones have been investigated in details to comprehend proxies behind the formation of good reservoirs, following the approach of Lindsay et al. (2006). These authors, who studied the Arab D reservoir properties in the Ghawar field in Saudi Arabia, subdivided the Arab D carbonates into seven limestone and four dolostone reservoir rock types, based on five main petrographic parameters (i.e. matrix, sorting, cement, pore type and size of largest moulds). In the present study, we aim at further defining the proxies that control reservoir properties to suggest useful trends obtained from proportional distribution maps (described above).

\section{Diagenesis quantification at the field scale}

The Arab D reservoir rock types

In the Arab D Member, well sorted, grain-supported rock textures with abundant syntaxial calcite overgrowth (SCO) cement reveal high porosity $(20-40 \%)$ and permeability (up to $1000 \mathrm{mD}$; sometimes even $10000 \mathrm{mD}$ ) values. Dolomitization occurs especially in the mud-supported rock textures in the northern part of the oilfield (cf. Fig. 9C), where the supratidal to lagoonal depositional realms prevail. The anhydrite lithofacies ranges from 1 to $75 \%$, and it is also concentrated in the north-eastern part of the field. Southwards, anhydrite average content decreases (ca. 1-7\%). Where muddy rock textures prevail, dissolution of the dolomite and anhydrite cement has produced significant intercrystalline and vuggy porosity.

The best reservoir rocks for the Arab D Member remain the nondolomitized, lime grainstone in the central and north-western parts of the oilfield (Fig. 9A, B), which have been deposited in the shoal environment seaward of the lagoonal realm. Following a more distal trend, the depositional realm becomes an outer ramp, with less grain-supported textures (and with lower reservoir quality). Hence, a semi-quantitative approach, based on lithology, rock texture and diagenesis interpolation maps, provides practical means (or proxies) for classifying such reservoirs at the scale of the field.

\section{The Arab $C$ reservoir rock types}

In the Arab C Member, grain-supported rock textures with good flow properties (porosity: 20-28\%; permeability: 2.5$250 \mathrm{mD}$ ) are less abundant compared with the Arab D Member, and they are characterized by almost complete absence of syntaxial and equant calcite cements. In contrast, dolomitized mud-supported textures, are more common, and have considerable flow properties (porosity: 2034\%; permeability: 6-2500 $\mathrm{mD}$ ), owing to dolomite and anhydrite dissolution, which produced intercrystalline and vuggy porosity. Dolostone samples with significant porosity are usually characterized by small amounts of anhydrite cement and by significant secondary porosities.

Across the investigated oilfield, the total average porosity for the Arab C Member varies from 6 to $19.5 \%$ and the average permeability reaches some $16 \mathrm{mD}$; still, the highest values (for both parameters) occur mainly in the southwestern part of the field (Fig. 10C,D). Such good reservoir properties are strongly associated with high degree of dolomitization (80-95\%), whereas anhydrite cements are absent to rare $(<6 \%)$. A working hypothesis for a proxy to define the best dolostone reservoir rocks for the Arab $\mathrm{C}$ Member appears to be involved with the anhydrite precipitation/ dissolution in the dolomitized distal shoal/outer ramp facies. For this reason, we use a smaller (plug) scale sample to visualize, quantify and simulate the effect of diagenesis on the pore system and petrophysics.

\section{Diagenesis quantification at the plug scale}

More adequate quantifications of the rock microstructure, components (e.g. anhydrite) and pore space are obtained by $3 \mathrm{D}$ image analysis of reconstructed $\mu$-CT sample volumes. Additionally, this technique provides the necessary input for PNM in which different petrophysical properties (e.g. MICP, permeability) can be determined rapidly. These 
analyses should focus on reference samples chosen according to the results of the above-presented statistical field maps and refer to time steps in the diagenetic evolution that are relevant for the modifications of the reservoir properties.

Here, a specific time-framed diagenetic process, for example cementation by anhydrite, is investigated, rather than the whole sequence of diagenetic events that affected the Arab $\mathrm{C}$ sequence. From the $\mu$-CT images, we could tell that the anhydrite is not homogeneously distributed, but tends to occur as nodules, discontinuous in $3 \mathrm{D}$, partly filling vuggy and intercrystalline porosity and to a lesser extent replacing dolomite crystals. This patchy $3 \mathrm{D}$ distribution of anhydrite has a negative impact on reservoir porosity, although the effect on permeability appears to be more profound. Anhydrite that occludes the vuggy pores may cause considerable increase in the overall rock permeability upon its dissolution. Eventually, distinct vugs become connected along enlarged intercyrstalline porosity (De Boever et al. 2012). The 3D $\mu$-CT images do not allow to separately quantify the anhydrite cement precipitated in pores and the minor anhydrite replacement of dolomite crystals. The visualized anhydrite phase is considered to represent only the cement phase (i.e. AC2 in Fig. 7).

\section{Integrated quantification approach}

The presented case study on the Arab reservoirs, which couples both classical diagenetic study (based on petrography) and statistical mapping at the scale of an oilfield, links sedimentological and diagenetic information from the thin section to the field scale. The study also provides some spatial diagenetic trends, which may explain the encountered distribution of reservoir properties (e.g. Koehrer et al. 2010). Here, image analyses of a large number of thin sections allow quantification in $2 \mathrm{D}$ and the creation of field maps. These maps are the basis for conducting further enhanced statistics on the sedimentological and diagenetic relationships (e.g. Barbier et al. 2012), eventually suggesting meaningful understanding of reservoir heterogeneities. Accordingly, the lime grainstones of the Arab D reservoirs, which contain syntaxial calcite overgrowth cement (SCO), include the best flow properties in the investigated oilfield. Conceptually, this is explained by the fact that the SCO cement helped in decreasing the effects of mechanical compaction and preserved considerable interparticle porosity. The diagenetic investigation and mapping across the investigated oilfield demonstrate that the presence of anhydrite cement deteriorates the reservoir properties of the Arab C dolostone. Where such anhydrite cement is dissolved or did not precipitate, the Arab $\mathrm{C}$ dolostone reservoirs have better porosity and permeability. Quantifying and modelling the reservoir petrophysical properties based on a realistic description of the pore space geometry (at the plug scale) did improve the understanding of the behaviour of the reservoirs and the effect of diagenetic overprinting (anhydrite cementation) on transport characteristics across the investigated oilfield.

Finally, both approaches have been demonstrated to be useful to quantify and explain reservoir heterogeneities at the field and plug scale. They also provide invaluable input data that are compulsory to proceed further towards meaningful numerical modelling (e.g. geostatistical, reactive transport; cf. Fig. 1C).

\section{CONCLUSIONS}

This contribution presents two distinct approaches, at the field and core plug scale, which allowed describing, explaining and ultimately quantifying reservoir heterogeneities (offshore oilfield in Abu Dhabi, U.A.E.). The conceptual model of marine evaporative dolomitization and associated diagenesis processes of the Arab D and C reservoirs has been illustrated with time and space statistical distribution of resulted rock textures and diagenetic phases across the investigated oilfield.

Quantification of the key diagenetic phases (such as syntaxial calcite overgrowth cement in Arab D grainstones), which impacted reservoir porosity and permeability, was achieved by constructing 2D proportional distribution maps based on well core data. Subsequently, trends and proxies for assessing the best reservoir rock types could be defined at the scale of the field.

The field-scale study allowed to identify the controls on reservoir development and the diagenetic events or phases most relevant for reservoir evolution. Nondolomitized lime grainstones (shoal deposits) are the most important in the Arab D. In contrast, development of the Arab C reservoir rock type is strongly controlled by its diagenetic evolution where the dissolution of anhydrite in dolomitized distal shoal/outer ramp deposits created important vuggy porosity.

$3 \mathrm{D}$ visualization and further quantification at the scale of a plug from the dolostones of the Arab C Member permit to understand the effect of anhydrite nodules on the pore system. The plug scale approach involved $2 \mathrm{D}$ and $3 \mathrm{D}$ image analyses, $\mu$-CT and pore network modelling, showing the possible changes in pore structure following anhydrite dissolution. It might allow to estimate the change in petrophysical properties of a rock type at former time steps in the diagenetic history.

\section{ACKNOWLEDGEMENTS}

The authors would like to thank IFP Energies nouvelles, the Petroleum Institute of Abu Dhabi and the Oil Subcommittee of Abu Dhabi National Oil Company (ADNOC) for permission to publish this research work. We especially thank Marwan Haggag and Omar Al-Farisi for 
the excellent coordination of the research collaboration between the Petroleum Institute of Abu Dhabi and ADNOC and its operating companies. Denis Deldique (IFP Energies nouvelles) is acknowledged for preparing the figures. Julien Schmitz (IFP Energies nouvelles) is also acknowledged for assistance with ArcGIS. Francois Roure and an anonymous referee are also acknowledged for their constructive comments that improved the quality of this article.

\section{REFERENCES}

Adams JE, Rhodes ML (1960) Dolomitization by seepage reflux. AAPG Bulletin, 44, 1912-20.

Ahr W (2008) Geology of Carbonate Reservoirs: The Identification, Description and Characterization of Hydrocarbon Reservoirs in Carbonate Rocks, 227p. John Wiley and Sons, Inc., New Jersey, USA.

Algive L, Bekri S, Lerat O, Nader F, Vizika O (2009a) Reactive Pore Network Modeling technology to evaluate the impact of diagenesis on the petrophysical properties of a rock. International Petroleum Technology Conference, 1-10.

Algive L, Bekri S, Vizika O (2009b) Reactive Pore Network Modeling Dedicated to the Determination of the Petrophysical Property Changes While Injecting $\mathrm{CO}_{2}$. SPE Annual Technical conference and Exhibition, 1-21.

Al-Kharusi AS, Blunt MJ (2008) Multiphase flow predictions from carbonate pore space images using extracted network models W06S01. Water Resources Research, 44, 1-14.

Alsharhahn AS (1989) Petroleum geology of the United-ArabEmirates. Journal of Petroleum Geology, 12, 253-88.

Alsharhahn AS, Whittle GL (1995) Carbonate-evaporite sequences of the Late Jurassic, Southern and Southwestern Arabian Gulf. AAPG Bulletin, 79, 1608-30.

Arns J-Y, Robins V, Sheppard AP, Sok RM, Pinczewski WV, Knackstedt MA (2004) Effect of network topology on relative permeability. Transport in Porous Media, 55, 21-46.

Arns C, Bauget F, Limaye A, Salemmariou A, Senden TJ, Sheppard AP, Sok RM, Pinczewski WV, Bakke S, Berge LI, Oren RE, Knackstedt MA (2005) Pore-scale characterization of carbonates using X-ray microtomography. 2004 SPE Annual Technical Conference and Exhibition, 475-84.

Barbier M, Hamon Y, Doligez B, Callot J-P, Floquet M, Daniel J-M (2012) Stochastic joint simulation of facies and diagenesis: a case study on early diagenesis of the Madison Formation (Wyoming, USA). Oil and Gas Science and Technology (OGST), $67,123-45$.

Butler GP (1969) Modern evaporative deposition and geochemistry of coexisting brines, the sabkha, Trucial Coast, Arabian Gulf. Journal of Sedimentary Petrology, 39, 70-89.

Cantrell DL, Hagerty RM (2003) Reservoir rock classification, Arab-D reservoir, Ghawar field, Saudi Arabia. GeoArabia, 8, 435-62.

Cantrell DL, Swart PK, Robertson CH, Kendal CG, Westphal $\mathrm{H}$ (2001) Geology and production significance of dolomite, Arab-D reservoir, Ghawar field, Saudi Arabia. GeoArabia, 6, $45-59$.

Consonni A, Ronchi P, Geloni C, Battistelli A, Grigo D, Biagi S, Gherardi F, Gianelli G (2010) Application of numerical modelling to a case of compaction-driven dolomitization: a Jurassic palaeohigh in the Po Plain, Italy. Sedimentology, 57, 209-31.
Davies GR, Smith LB (2006) Structurally controlled hydrothermal dolomite reservoir facies: an overview. AAPG Bulletin, 90, 1641-90.

De Boever E, Varloteaux C, Nader FH, Foubert A, Bekri S, Youssef S, Rosenberg E (2012) Quantification and prediction of the 3D pore network evolution in carbonate reservoir rocks. Oil and Gas Science and Technology (OGST), 67: 161-78.

Dickson JAD (1966) Carbonate identification and genesis as revealed by staining. Journal of Sedimentary Petrology, 36, 491-505.

Ehrenberg SN, Nadeau PH, Aqrawi AAM (2007) A comparison of Khuff and Arab reservoir potential throughout the Middle East. AAPG Bulletin, 91, 275-86.

Esrafili-Dizaji B, Rahimpour-Bonab H (2009) Effects of depositional and diagenetic characteristics on carbonate reservoir quality: a case study from the South Pars gas field in the Persian Gulf. Petroleum Geoscience, 15, 325-44.

Flukiger F, Bernard D (2009) A new numerical model for pore scale dissolution of calcite due to $\mathrm{CO}_{2}$ saturated water flow in 3D realistic geometry: principles and first results. Chemical Geology, 265, 171-80.

Folk RL, Land LS (1975) Mg/Ca ratio and salinity: two controls over crystallization of dolomite. AAPG Bulletin, 59, 60-8.

Fontana S, Nader FH, Morad S, Ceriani A, Al-Aasm IS (2010) Diagenesis of the Khuff Formation (Permian-Triassic), northern United Arab Emirates. Arab Journal of Geoscience (Springer), 3, 351-68.

Fontana S, Nader FH, Morad S, Ceriani A, Al-Aasm IS, Daniel J-M, Mengus J-M (in press) Evolution of fluid-rock interactions associated to regional tectonics and basin history: an example from Permo-Triassic carbonates of U.A.E. Sedimentology (in press).

Gasparrini M, Bechstädt T, Boni M (2006) Massive hydrothermal dolomites in the southwestern Cantabrian Zone (Spain) and its relation to the late Variscan evolution. Marine and Petroleum Geology, 23, 543-68.

Grötsch J, Suwaina O, Aglanji G, Taher A, El-Khassewneh R, Lokier S, Coy G, Van der Weerd E, Masalmeh S, Van dorp J (2003) The Arab Formation in central Abu Dhabi: 3-D reservoir architecture and static and dynamic modeling. GeoArabia, 8, 47-86.

Hanor JS (2004) A model for the origin of large carbonate- and evaporite-hosed celestine (SrSO4) deposits. Journal of Sedimentary Research, 74, 169-75.

Humphrey JD (1988) Late Pleistocene mixing zone dolomitization, southeastern Barbados, West Indies. Sedimentology, 35, 327-48.

Jones GD, Xiao Y (2005) Dolomitization, anhydrite cementation, and porosity evolution in a reflux system: insights from reactive transport models. AAPG Bulletin, 89, 577-601.

Kaufman J (1994) Numerical models of fluid flow in carbonate platforms; implications for dolomitization. Journal of Sedimentary Research, 64, 128-39.

Knackstedt MA, Arns C, Limaye A, Senden T, Sheppard AP, Pinczewski WV, Bunn GF (2004) Digital Core Laboratory: Properties of reservoir core derived from 3D images. SPE Asia Pacific Conference on Integrated Modelling for Asset Management.

Knackstedt MA, Arns C, Ghous A, Sakellariou A, Senden T, Sheppard AP, Sok RM, Averdunk H, Pinczewski WV, Padhy GS, Ioannidis MA (2006) 3D imaging and flow characterization of the pore space of carbonate core samples. SCA2006-23. International Symposium of the Society of Core Analysts, 1-13.

Koehrer BS, Heymann C, Prousa F, Aigner T (2010) Multiplescale facies and reservoir quality variations within a dolomite 
body - Outcrop analog study from the Middle Triassic, SW German Basin. Marine and Petroleum Geology, 27, 386-411.

Lapponi F, Casini G, Sharp I, Blendinger W, Ferna'ndez N, Romaire I, Hunt D (2011) From outcrop to 3D modelling: a case study of a dolomitized carbonate reservoir, Zagros Mountains, Iran. Petroleum Geoscience, 17, 283-307.

Laroche C, Vizika O, Hamon G, Courtial R (2001) Two Phase Flow Properties Prediction from Small Scale Data using PoreNetwork Modelling. SCA 2001-16, Edinburgh, UK.

Lindsay RF, Cantrell DL, Hughes GW, Keith TH, Mueller HW, Russel SD (2006) Ghawar Arab-D reservoir: widespread porosity in shoaling-upward carbonate cycles, Saudi Arabia. In: Giant Hydrocarbon Reservoirs of The World: From Rocks to Reservoir Characterization and Modelling (eds Harris PM, Weber LJ), pp. 97-137. AAPG Memoir 88/SEPM Special Publication, Tulsa, OK, USA.

Long H, Swennen R, Foubert A, Dierick M, Jacobs P (2009) 3D quantification of mineral components and porosity distribution in Westphalian C sandstone by microfocus X-ray-computed tomography. Sedimentary Geology, 220, 116-25.

Lønøy A (2006) Making sense of carbonate pore systems. AAPG Bulletin, 90, 1381-405.

López-Horgue MA, Iriarte E, Schröder S, Fernández-Mendiola PA, Caline B, Corneyllie H, Frémont J, Sudrie M, Zerti S (2010) Structurally controlled hydrothermal dolomites in Albian carbonates of the Asón valley, Basque Cantabrian Basin, Northern Spain. Marine and Petroleum Geology, 27, 1069-92.

Lucia FJ (1999) Carbonate Reservoir Characterization, 226p. Springer, New York.

Machel HG (1986) Early lithification, dolomitization, and anhydritization of Upper Devonian Nisku buildups, subsurface of Alberta, Canada. In: Reef Diagenesis (eds Scroeder JH, Purser $\mathrm{BH})$, pp. 336-56. Springer Verla, Berlin.

Machel HG, Burton EA (1994) Golden grove dolomite, Barbados; origin from modified seawater. Journal of Sedimentary Research, A64, 741-51.

Mattes BW, Mountjoy EW (1980) Burial dolomitization of the Upper Devonian Miette buildup, Jasper National Park, Alberta. In: Concepts and Models of Dolomitization (eds Zenger DH, Dunham JB, Ethington RL), pp. 259-97. SEPM Spec. Publ., 28, SEPM, Tulsa, OK, USA.

Merino E, Canals A (2011) Self-accelerating dolomite-for-calcite replacement: self-organized dynamics of burial dolomitization and associated mineralization. American Journal of Science, 311, 573-607.

Meyer FO, Price RC, Al-Ghamdi IA, Al-Goba IM, Al-Raimi SM, Cole JC (1996) Sequential stratigraphy of outcropping strata equivalent to Arab-D reservoir, Wadi Nisah, Saudi Arabia. GeoArabia, 1, 435-56.

Morad S, Al-Aasm IS, Nader FH, Ceriani A, Gasparrini M, Mansurbeg H (2012) Impact of diagenesis on the spatial and temporal distribution of reservoir quality in the Jurassic Arab D and $\mathrm{C}$ Members, offshore Abu Dhabi oilfield, United Arab Emirates. GeoArabia, 17, 17-56.

Morrow DW, Ricketts BD (1988) Experimental investigation of sulphate inhibition of dolomite and its mineral analogues. In: Sedimentology and Geochemistry of Dolostones. Society of Economic Paleontologists and Mineralogists (eds Shukla V, Baker PA), pp. 25-39. SEPM Special Publication, 43, SEPM, Tulsa, OK, USA.

Muchez P, Viaene W (1994) Dolomitization caused by water circulation near the mixing zone: an example from the Lower Viséan of the Campine Basin (northern Belgium). In: Dolomites - A Volume in Honour of Dolomien (eds Purser BH, Tucker
ME, Zenger DH), pp. 155-66. SEPM Spec. Publ., 21, SEPM, Tulsa, OK, USA.

Murris RJ (1980) Middle East: stratigraphic evolution and oil habitat. AAPG Bulletin, 64, 597-618.

Nader FH, Swennen R, Ellam R (2004) Stratabound dolomite versus volcanism-associated dolomite: an example from Jurassic platform carbonates in Lebanon. Sedimentology, 51, 339-60.

Nader FH, Swennen R, Ellam R (2007) Field geometry, petrography and geochemistry of a dolomitization front (Late Jurassic, central Lebanon). Sedimentology, 54, 1093-110.

Rahimpour-Bonab H, Esrafili-Dizaji B, Tavakoli V (2010) Dolomitization and anhydrite precipitation in Permo-Triassic carbonates at the South Pars gasfield, offshore Iran: controls on reservoir quality. Journal of Petroleum Geology, 33, 43-66.

Rhodes ME, Bijeljic B, Blunt MJ (2008) Pore-to-field simulation of single-phase transport using continuous time random walks. Advances in Water Resources, 41, 1527-39.

Ronchi P, Jadoul F, Ceriani A, Di Giulio A, Scotti P, Ortenzi A, Fantoni R (2011) Multistage Dolomitization in an Early Jurassic Platform (Southern Alps, Italy): insights for the distribution of massive dolomitized bodies. Sedimentology, 58, 532-65.

Roure F, Swennen R, Schneider F, Faure JL, Ferket H, Guilhaumou N, Osadetz K, Robian P, Vandeginste V (2005) Incidence and importance of tectonics and natural fluid migration on reservoir evolution in foreland fold-and-thrust belts. Oil and Gas Science and Technologie (OGST), 60, 67-106.

Saller AH (1984) Petrologic and geochemical constraints on the origin of subsurface dolomite, Enewatak Atoll: an example of dolomitization by normal seawater. Geology, 12, 217-20.

Simms MA (1984) Dolomitization by groundwater-flow systems in carbonate platforms. Transactions Gulf Coast Association of Geological Societies, 34, 411-20.

Slaughter M, Hill RJ (1991) The influence of organic matter in organogenic dolomitization. Journal of Sedimentary Research, 61, 296-303.

Swart PK, Cantrell DL, Westphal H, Handford CR, Kendall CG (2005) Origin of dolomite in the Arab-D reservoir from the Ghawar Field, Saudi Arabia: evidence from petrographic and geochemical constraints. Journal of Sedimentary Research, 75, 476-91.

Swennen R, Dewit J, Fierens E, Muchez P, Shah M, Nader F, Hunt D (2012) Multiple dolomitization events along the Pozalagua Fault (Pozalagua Quarry, Basque-Cantabrian Basin, Northern Spain). Sedimentology, 59, 1345-74.

Turpin M, Nader FH, Kohler E (2012) Empirical calibration for dolomite stoichiometry calculation: application on Triassic Muschelkalk-Lettenkohle carbonates (French Jura). Oil and Gas Science and Technology (OGST), 67, 77-95.

Vasconcelos C, McKenzie JA (1997) Microbial mediation of modern dolomite precipitation and diagenesis under anoxic conditions (lagoa Vermelha, Rio de Janeiro, Brazil). Journal of Sedimentary Research, 67, 378-91.

Veizer J, Ala D, Azmy K, Bruckschen P, Buhl D, Bruhn F, Carden GAF, Diener A, Ebneth S, Godderis Y, Jasper T, Korte C, Pawellek F, Podlaha OG, Strauss H (1999) ${ }^{87} \mathrm{Sr} /{ }^{86} \mathrm{Sr}, \delta^{13} \mathrm{C}$ and $\delta^{18} \mathrm{O}$ evolution of Phanerozoic seawater. Chemical Geology, 161, 59-88.

Ward WC, Halley RB (1985) Dolomitization in a mixing zone of near-seawater composition, Late Pleistocene, north-eastern Yucatan Peninsula. Journal of Sedimentary Petrology, 55, 407-20.

Wright DT (1997) An organogenic origin for widespread dolomite in the Cambrian Eilean Dubh Formation, northwestern Scotland. Journal of Sedimentary Research, 67, 54-65.

Youssef S, Rosenberg E, Gland N, Bekri S, Vizika O (2007a) Quantitative 3D characterisation of the pore space of real 
rocks: improved $\mu$-CT resolution and pore extraction methodology. International symposium of the Society of Core Analysts, 1-13.

Youssef S, Rosenberg E, Gland N, Skalinski M, Vizika O (2007b) High resolution CT and pore-network models to assess petrophysical properties of homogeneous and heterogeneous carbonates. SPE 111427. SPE/EAGE Reservoir Characterization and Simulation Conference, 1-12.

Youssef S, Han M, Bauer D, Rosenberg E, Bekri S, Fleury M, Vizika O (2008) High resolution $\mu$-CT combined to numerical models to assess electrical properties of bimodal carbonates. International Symposium of Core Analysts, 1-12. 


\title{
GEOFLUIDS
}

\author{
Volume 13, Number 2, May 2013 \\ ISSN 1468-8115
}

\section{CONTENTS}

99 EDITORIAL: 2012 Paris Geofluids VII Conference Summary \& Thematic Issue

Rudy Swennen, Francois Roure, Jacques Pironon, Fadi H. Nader and Mark Person

101 Synchrotron XRF and XANES investigation of uranium speciation and element distribution in fluid inclusions from unconformity-related uranium deposits

A. Richard, J. Cauzid, M. Cathelineau, M.-C. Boiron, J. Mercadier and M. Cuney

112 Age and genesis of the White Pine stratiform copper mineralization, northern Michigan, USA, from paleomagnetism

D.T.A. Symons, K. Kawasaki and J.F. Diehl

127 Modelling fault reactivation and fluid flow around a fault restraining step-over structure in the Laverton gold region, Yilgarn Craton, Western Australia

Y. Zhang, P.M. Schaubs, H.A. Sheldon, T. Poulet and A. Karrech

140 Fluid channeling along thrust zones: the Lagonegro case history, southern Apennines, Italy T. Gabellone, M. Gasparrini, A. Iannace, C. Invernizzi, S. Mazzoli and M. D'Antonio

159 Diagenesis versus hydrothermalism and fluid-rock interaction within the Tuscan Nappe of the Monte Amiata $\mathrm{CO}_{2}$-rich geothermal area (Italy)

M. Gasparrini, G. Ruggieri and A. Brogi

180 Diagenetic evolution of a fractured evaporite deposit (Vilobí Gypsum Unit, Miocene, NE Spain) M. Moragas, C. Martínez, V. Baqués, E. Playà, A. Travé, G. Alías and I. Cantarero

194 Geochemical simulations to assess the fluorine origin in Sierra de Gador groundwater (SE Spain) L. Daniele, M. Corbella, A. Vallejos, M. Díaz-Puga and A. Pulido-Bosch

204 Quantification of diagenesis impact on the reservoir properties of the Jurassic Arab $D$ and $C$ members (Offshore, U.A.E.)

F.H. Nader, E. De Boever, M. Gasparrini, M. Liberati, C. Dumont, A. Ceriani, S. Morad, O. Lerat and B. Doligez

221 Dedolomitization and reservoir quality: insights from reactive transport modelling L-.C. Escorcia, E. Gomez-Rivas, L. Daniele and M. Corbella

232 Reflux dolomitization of the Upper Permian Changxing Formation and the Lower Triassic Feixianguan Formation, NE Sichuan Basin, China L. Jiang, C.F. Cai, R.H. Worden, K.-K. Li and L. Xiang

246 Petroleum system evolution in the inverted Lower Saxony Basin, northwest Germany: a $3 D$ basin modeling study

B. Bruns, R. Di Primio, U. Berner and R. Littke 